\title{
Development of British Colonial Education in Malaya, 1816 - 1957
}

\section{Ganesan Shanmugavelu}

Senior Lecturer of History, Institute of Teacher Education (Ipoh Campus), Malaysia

\section{OPEN ACCESS}

Volume: 8

Issue: 2

Month: March

Year: 2020

P-ISSN: 2320-2653

E-ISSN: 2582-1334

Received: 05.01.2020

Accepted: 07.02.2020

Published: 01.03.2020

Citation:

Shanmugavelu, Ganesan. et al. "Development of British Colonial Education in Malaya, 1816 - 1957.”

Shanlax International Journal of Education, vol. 8, no. 2, 2020, pp. 10-15.

DOI:

https://doi.org/10.34293/

education.v8i2.2072

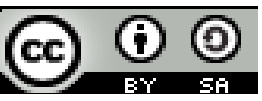

This work is licensed under a Creative Commons Attribution-ShareAlike 4.0 International License

\section{Khairi Ariffin}

Associate Professor of History, Sultan Idris Education University, Malaysia

\section{Nadarajan Thambu}

Senior Lecturer of Moral Education, Sultan Idris Education University, Malaysia

\section{Zulkufli Mahayudin}

Senior Lecturer of Educational Studies, Institute of Teacher Education (Ipoh Campus), Malaysia

\section{Abstract}

The aim of this study is to discuss the development of education during the British Colonial rule in Malaya. The scope of this study is focussed on four school systems under British colonialists, namely the Malay Vernacular School, Chinese Vernacular School, Tamil Vernacular School, and English Schools and its implications to the society and nation. The introduction of these four school systems is aimed at the economic and political interests of the British in Malaya. The Colonial Education System does not have a National Education Policy and brings many implications to the society and nation. It has caused class and status disparities among the societies and also caused socio-economic differences between races in Malaya. The process of socialization is not achieved among all races in Malaya under the Colonial Education. This study is qualitative and is approached through the library and archival research.

Keywords: Development, Colonial, Education, Vernacular, Schools

\section{Introduction}

The Education system in Malaya has already existed before the arrival of colonial powers, but it is different from what was introduced by the British. Before the arrival of colonial powers, education in Malaya was non-formal and burdened the cognitive development of students. (Abdullah Sani \& P.Kumar, 1990, p.1). The education system during that period was the religious education system (Pondok School). Schools at that time did not devote time to teach reading, writing and arithmetic lessons or providing job skills, but devoted time to religious teaching. (Abu Zahari, 1980, p.6).

This old education system has undergone significant change after the arrival of the British colonialist to Malaya. The British have introduced a systematic system of education. At this stage (1824-1957), education in Malaya was managed, controlled, and placed under the British colonial power without having a concrete philosophy or National Education Policy. (Abdullah Sani \& P.Kumar, 1990, p.1). The education system that existed during the British administration was four school systems, namely the Malay Vernacular School, Chinese Vernacular School, Tamil Vernacular School, and English Schools. 
According to Ibrahim Saad, there are three main goals of education during the colonial period, as follows:

- Schools have the purpose of socializing children with foreign values and not the native values

- Schools have appointed a small group of indigenous people (especially from traditional leaders) to meet their specific goals.

- Schools operate to fulfill the workforce requirements at a minimum and the lowest level. (Ibrahim Saad, 1990, p.7)

The three goals above shows that the purpose of the British to introduce the education system in Malaya is for the benefit of the British itself, which is for economic and political purposes and not for the benefit of natives or immigrants. Apart from these three goals, there are also other reasons in the British education system in Malaya. The reasons are:

a. Strengthen the British Empire trade machinery in Southeast Asia.

b. Provide training to lower administrative officers.

c. Providing workers who can assist the British in trading.

d. Providing energy in the construction of roads and railways.

e. Providing workforce in soil planning and rubber discovery.

f. Providing education and training to the Malays to carry out agricultureand fishing activities more effectively

g. Educating the public to become responsible citizens of the British.

h. Maintain a peaceful situation in Malaya.

i. Build a society that can serve the interests and policies of British colonists.

The goals of the British education policy above clearly shows that the main goal of the colonial education system is to provide education to a group of people to enable them to meet the needs of the workforce and economy. (Abdullah Sani \& P.Kumar, 1990, p.1)

\section{Malay Vernacular School}

During the British rule in Malaya, Malay schools were established for certain purposes. The main purpose of establishing Malay schools in the 19th and early 20th centuries are to enable Malays to continue living in villages, to inherit the poverty of their families, and to help their parents. Therefore, secular education in the Malay language is limited to four years with limited scope and curriculum. (Abdullah Sani \& P.Kumar, 1990, p.3).

The first Malay school was established in Glugor, Penang, in the year 1921. But the achievement of this school is not something to be proud of. In 1856, two schools were established in Singapore, namely the Teluk Belanga Malay School and Kampung Gelam Malay School. In 1905, Malay College Kuala Kangsar (MCKK) was established. The formation of this College is important to understand the dualism policy in British colonial education for the Malays. (hard. Jadi, 1990, p.13). Indeed, the setting up of the Malay College Kuala Kangsar is special for the upper-class Malays and the Malay Rulers. They will be given the knowledge in English so that they can be controlled by the British.

The British had made some changes to the Malay Education System by setting up a Teachers College to train theMalay Teachers. The Malay school system came to its heights in 1922 when the Sultan Idris Teachers College in Tanjung Malim, Perak, was established. (hard. Jadi, 1990, p.12). This college will train Malay teachers who will return to the village and teach the farmer's children to become farmers as well. Overall, education provided to the Malays by the British through the Malay Vernacular School can be seen as "Education is used as a means of controlling the Malays not to oppose its power and school is used as a social control tool." (Ibrahim Saad, 1977, p.12).

\section{Chinese Vernacular School}

Chinese immigrants came into Malaya in the late 17 th and early 18 th centuries. The arrival of the Chinese has enabled Chinese schools to be established in Malaya for this generation of newcomers. The development of Chinese Education in Malaya is closely linked to the economic factors in the region. In 1915, the first Chinese school was established in Malaya by members of the London missionary. The Chinese school, founded in Malaya, is the same pattern as schools in mainland China. The development of Chinese schools in Malaya was not well regarded by British colonialists. 
Beginning in 1901, the Manchu Government has provided financial assistance to schools in Malaya with the aim that the Chinese in Malaya will support the Manchu administration in China. In 1911, there were about 56 Chinese Vernacular Schools in Malaya, and these schools had Kuomintang's influence. During this period, Chinese schools are not controlled by the British, but the situation changed beginning from 1920 when the Chinese schools became the venue for a subversive and political movement, the government passed the law to examine the schools. (HarisMd.Jadi, 1990, p.14).

The situation in Chinese schools has been increasingly stringent when in 1925, the amendments to the School Enactment gave power to the Director of Education. It has been a long period since the Chinese school became a source of anxiety for the British colonialists. Almost all the teachers are brought from China, and the entire field of study was not suitable to build the personality of Malaya, and some were encouraging racial disunity. (Ibrahim Saad, 1977, p.36). The whole development of the Chinese Vernacular School in Malaya was not very concerned by the British. When the Kuomintang influence began to flow into Chinese schools, the British government took appropriate steps to control the Chinese School.

\section{Tamil Vernacular School}

The setting up of the Tamil Vernacular schools in Malaya began after the establishment of the Penang Free School in 1816. The arrival of Indian immigrants, especially to work in the plantations, has led to the establishment of Tamil schools. The establishment of the Tamil Vernacular School depends on their employer or the efforts of the Missionary Association. For example, in 1895, St. Francis Xavier Malabar Tamil School was established by the Christian missionary group in Singapore. (Mok Soon Sang \& Lee Shok Mee, 1988, p.19).

The development of Tamil schools is very disappointing. The British and the rubber planters do not provide any assistance either physically, financially, or pedagogy. What is obvious is that these schools are not fully functional, and most of the students will stay in rubber estates and become laborers. According to S.Arasaratnam, for all these years, the whole system of Tamil education in Malaya was nothing but a sham and a mockery. (S.Arasaratnam, 1970, p.181).

Also, the curriculum of Tamil schools is also adapted to the situation that occurs in India. Textbooks are imported from India and provide knowledge of the Indian culture, history, and geography of India, but didn't emphasize anything about Malaya. Any learning that occurs during the short period of an Indian child living in the plantation and goes to the school is entirely oriented to India. (B.W.Andaya \& L.Y.Andaya, 1983, p.258).

Beginning in 1905, the British government decided to set up Tamil Schools. In 1914, Vivekananda Tamil School was established. Changes occurred in 1925 when the Labor Code was enforced, which states that schools should be established in any estates with more than ten children. Overall, it may be noted that the recent development of the Tamil Vernacular Schools in Malaya is not something to be proud of as the Indian community in Malaya still ignores education.

\section{English School}

The establishment of the English Schools in Malaya begins earlier than the Vernacular schools. English education was first introduced in Malaya when Penang Free School was established in 1816. The school curriculum is based on the Grammar School of Great Britain curriculum to produce Lower Administrative Officers to meet the needs of the British Metropolitan policies. (Abdullah Sani \& P.Kumar, 1990, p.5).

During the British Colonial era, English schools were divided into two types. The first type is the Free School which received assistance from the government and was under its auspices until the government took over its power. The second type is the Great-in-Aid English School established and funded by missionary associations with financial assistance from the government. (Abu Zahari, 1980, p.30).

Most English Schools are only established in cities. Chinese and Indian children living in cities are a large number of students in English schools. Because of its location in cities and high fees for 
studying in this school, the Malays living in rural areas had difficulties to enter into this school due to transportation and financial problems. The poor people living in the city also can't afford to study in English schools. (Haris Md. Jadi, 1990, p.18).

\section{Implications of the Colonial Education System to the Society and Nation}

Indeed, the Colonial Education System has created some implications for society and the nation. Colonial Education has created four school systems, namely Malay Vernacular School, Chinese Vernacular School, Tamil Vernacular School, and English School, but there is no concrete philosophy and National Education Policy. There is no standard policy on the use of Language, Curriculum Content, Textbook, Teacher Training, and Exam. (Abdullah Sani \& P.Kumar, 1990, p.18).

The Malay education system, which was introduced through the Malay Vernacular School is restricted to the basic level only. The British Education Policy for Malays through the Malay Vernacular School had frozen the Malays by keeping them within the confines of modern economic activity. This British Education Policy has suppressed the aspirations of the Malays by restricting the opportunities of the Malays to expand their talents. The vast majority of Malays are also separated from the upsurge of large socio-economic changes occurring in their lives. (Abu Zahari, 1980, p.18).

It can be seen that Chinese Vernacular Schools teaches China-oriented matters, and TamilVernacular Schools teaches India-oriented matters. As a result, Chinese and Indian children are not prepared for life in Malaya but have been prepared for life in China and India. This child are not exposed or know about indigenous peoples, and schools do not provide them for the environment in Malaya.(Ibrahim Saad, 1990, p.11)

English schools are only established in cities, and they are separate from indigenous cultures, not only in terms of language but also in terms of community values. Syllabus in English schools emphasizes things that have nothing to do with Malaya, and English Education has also led the society to achieve a new social standard as well as a new culture. Schools are no longer the agency that socializes children into their society, but schools have prepared the children into a foreign society. The foreign society in question is a concept of society and culture according to the composition and views of the colonial administrators in Malaya. (Ibrahim Saad, 1990, p.9).

British Colonial Education has also provoked a sense of racism or feelings of racism. Since each type of school is dedicated to a particular race, the schools are separated from one another according to geographical location and population distribution. (Abdullah Sani \& P.Kumar, 1990, p.5). What is clear is that schools have been the main tool for cultivating children in Malaya in different orientations. Schools have also become institutions for the children to focus on their race and separate them from one race to another. The Malay, Chinese, and Indian children are hard-pressed to mingle with each other. At that time, there was no spirit of patriotism towards Malaya as a whole, but it's more of spirit to their race and ethnic group. (Ibrahim Saad, 1977, p.40).

In the meantime, British Colonial Education has also widened the gap between the elite group and the ordinary people in Malaya. Under the Colonial Education Policy, some schools are set up to train leaders to work in government. For example, those who enter the Malay College Kuala Kangsar (MCKK) are made up of elites from the upper class and Malay rulers. The masses or ordinary people will attend the Malay Vernacular School, and they must follow and adhere to these elites. The implication is, the gap in the Malay community is not closed but is continued and expanded by the British education system. School is not the great equalizer', but become 'the great divider.' (Ibrahim Saad, 1977, p. 40).

Colonial education has also caused class and status disparities among societies. Some of the students attending a certain school get a better economic reward. Therefore, there is a class difference based on economic rewards. For example, students with English Education get good rewards, while students from the Malay, Chinese and Tamil schools get less reward. (Ibrahim Saad, 1977, p.40)

Also, the Colonial Education also caused the socio-economic differences between races in Malaya. Socially, it is clear that Chinese and Tamil 
schools play a role as a place to defend their culture and identity. The process of socialization among all races is not achieved because the community is educated separately based on the identity of the races themselves. As a result, inter-racial social life is also different, and the three races in Malaya are not united as a whole.

The Colonial Education Policy has also led to a disproportionate economic situation among the races. Malay education has, for instance, isolated the Malays from industrial and urban developmen, $t$ which is closely related to the emergence of 'British Malaya' as a major rubber and tin-producing country in the world. (Abu Zahari, 1980, p.18). The Malays continue to settle in the village by working in the paddy fields; the Indian community continues to live in rubber estates, while the Chinese community engages in business.

Another implication that can be seen through the Colonial Education system is the absence of an integrated national conscience among the Malayan population. The spirit of nationalism that exists among the people in Malaya is not integrated, and there is no racial equality. According to Haris Md. Jadi, there are Malay Nationalist movements, while in the other part, there are also immigrant ethnic nationalism movements resembling their native countries. (Haris Md. Jadi, 1990, p.23-24). This situation exists because of the British Education System, which provides separate education to Malays, Chinese, and Indians.

\section{Conclusion}

Through this article, we have a clear of the development of Colonial Education in Malaya during the British colonial period. It is evident that the pattern of education given to the Malayan population is different according to the race, namely through Malay Vernacular School, Chinese Vernacular School, Tamil Vernacular School, and English School. It can be seen that Colonial Education has brought many implications to the people and the country. This British Education Policy can also be seen as the basis of the Education Policies that were introduced later in Malaya to form a unified Malaysian society and show a spirit of loyalty to the nation.

\section{References}

Abdullah Sani and Kumar, P. Education in Malaysia. Longman, 1990.

Abu Zahari Abu Bakar. Perkembangan pendidikan di Semenanjung Malaysia: zaman sebelum merdeka hingga ke zaman sesudah merdeka, Penerbit Fajar Bakti, Kuala Lumpur, 1980.

Arasaratnam Sinappah. Indians in Malaysia and Singapore, Oxford University Press, London, 1970.

Barbara, W.A. and Leonard Y. Andaya. A History of Malaysia, Macmillan Publishers, New York, 1983.

Chan, P. Education Development in a Plural Society: A Malaysian Case Study, Malayan Publishing Co, 1970.

Haris Md Jadi. Ethnicity, Politics and Education, Language and Literature Council, 1990.

Hashim, Rosnani. Educational Dualism in Malaysia: Implications for Theory and Practice, Oxford University Press, New York, 1996.

Hussin. Education in Malaysia: History, Systems and Philosophy, Language and Library Council, 1993.

Milne, R.S. and Diane K. Mauzy. Politics and Government in Malaysia, Houghton Mifflen Co, Boston, 1977.

Mok, Soon Sang and Lee, Shok Mee. Education in Malaysia, Publisher of Budiman Group, 1988.

Saad, Ibrahim. Education and politics in Malaysia, Language and Literature Council, 1977.

Saad, Ibrahim. Education Change in Malaysia: A Challenge, DBP, 1990.

Singh, Saran Kaur Delip et al. "Impact of Chinese Vernacular Medium of Instruction on Unity in Multi-Ethnic Malaysia." Pertanika Journal of Social Science and Humanities, vol. 21, no. 3, 2013, pp. 1039-1064.

Tan Liok Ee. The Politics of Chinese Education in Malay, 1945-1961, Oxford University Press, 1997.

Wicks, Peter. "Education, British Colonialism, and a Plural Society in West Malaysia: The Development of Education in the British Settlements along the Straits of Malacca, 17861874." History of Education Quarterly, vol. 20, no. 2, 1980, pp. 163-187. 
Whitehead, Clive. "The Concept of British Education Wong, Hoy Kee YK. Perspectives: The Development Policy in the Colonies 1850-1960." Journal of Education in Malaysia and Singapore, of Educational Administration and History, Heinemann Educational Books, 1971. vol. 39 , no. 2007 , 2007, pp. 161-173.

\section{Author Details}

Ganesan Shanmugavelu, Senior Lecturer of History, Institute of Teacher Education (Ipoh Campus), Malaysia,

Email ID: drganesan68@gmail.com

Khairi Ariffin, Associate Professor of History, Sultan Idris Education University, Malaysia,

Email ID: Khairi.ariffin@fsk.upsi.edu.my

Nadarajan Thambu, Senior Lecturer of Moral Education, Sultan Idris Education University, Malaysia,

EmailID:nada@fsk.upsi.edu.my

Zulkufli Mahayudin, Senior Lecturer of Educational Studies, Institute of Teacher Education (Ipoh Campus), Malaysia,EmailID: zulkufl@ipgmipoh.edu.my 